OAK RIDGE
NATIONAL
LABORATORY

MALTIN MARAETTA
Electric-Utility DSM Programs in a Competitive Market

\author{
Eric Hirst
}

\section{MANAGED BY}

MARTIN MARIETTA ENERGY SYSTEMS, INC.

FOR THE UNITEO STATES

DEPARTMENT OF ENERGY 
This report has been reproduced directly from the best available copy.

Available to DOE and DOE contractors from the Office of Scientific and Technical Information, P.O. Box 62, Oak Ridge, TN 37831; prices available from (615) 576-8401, FTS 626.8401.

Available to the public from the National Technical Information Service, U.S. Department of Commerce, 5285 Port Royal Rd., Springfield, VA 22161.

This report was prepared as an account of work sponsored by an agency of the United States Government. Neither the United States Government nor any agency thereof, nor any of their employees, makes any warranty, express or implied, or assumes any legal liability or responsibility for the accuracy, completeness, or usefulness of any information, apparatus, product, or process disclosed, or represents that its use would not infringe privately owned rights. Reference herein to any specific commercial product, process, or service by trade name, trademark, manufacturer, or otherwise, does not necessarily constitute or imply its endorsement, recommendation, or favoring by the United States Government or any agency thereof. The views and opinions of authors expressed herein do not necessarily state or reflect those of the United States Government or any agency thereof. 


\title{
ELECTRIC-UTILITY DSM PROGRAMS IN A COMPETITIVE MARKET
}

\author{
ERIC HIRST \\ April 1994 \\ Sponsored by \\ Office of Energy Efficiency and Renewable Energy \\ U.S. Department of Energy \\ OAK RIDGE NATIONAL LABORATORY \\ Oak Ridge, Tennessee 37831 \\ managed by \\ MARTIN MARIETTA ENERGY SYSTEMS, INC. \\ under contract No. DE-AC05-84OR21400 \\ for \\ U.S. DEPARTMENT OF ENERGY
}




\section{CONTENTS}

Page

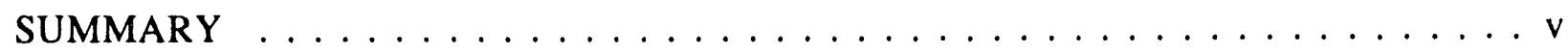

LIST OF ACRONYMS $\ldots \ldots \ldots \ldots \ldots \ldots \ldots \ldots \ldots \ldots \ldots \ldots$

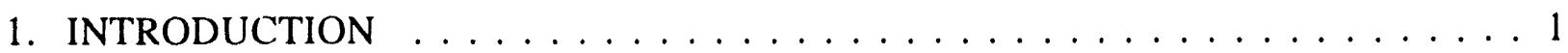

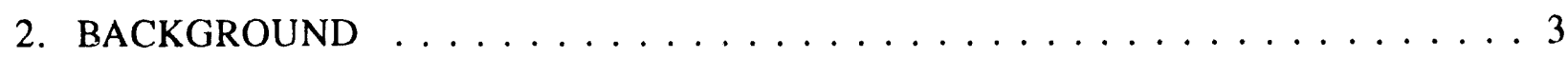

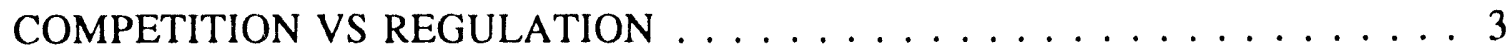

FORMS OF COMPETITION IN THE ELECTRIC-UTILITY INDUSTRY $\ldots . .5$

3. STATE REGULATION OF RETAIL COMPETITION . . . . . . . . . . 9

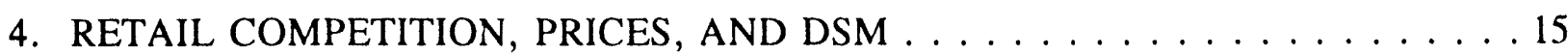

5. DESIGNING DSM PROGRAMS TO LOWER RATE IMPACTS . . . . . . . . . 19

6. POSSIBLE EFFECTS OF DSM ON UTILITY SHAREHOLDERS $\ldots \ldots \ldots 27$

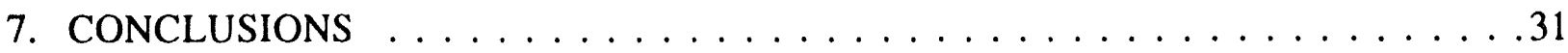

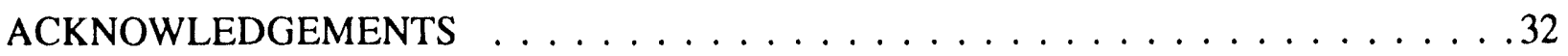

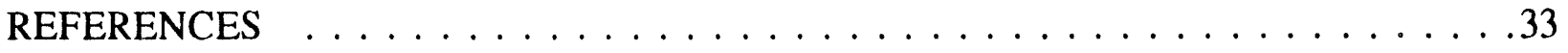




\section{SUMMARY}

During the past few years, the costs and effects of utility demand-side management (DSM) programs have grown sharply. In 1989, U.S. electric utilities spent $0.5 \%$ of revenues on such programs and cut total electricity consumption by $0.6 \%$. By 1992 , these numbers had increased to $1.3 \%$ and $1.2 \%$, respectively. Utility projections, as of early 1993, of DSM expenditures and energy savings for 1997 were $1.7 \%$ and $2.5 \%$, respectively.

Whether this projected growth comes to pass may depend on current debates about deregulation of, and increased competition in, the electric-utility industry. This report examines the factors likely to affect utility DSM programs in a more competitive environment.

The electric-utility industry faces two forces that may conflict with each other. One is the pressure to open up both wholesale and retail markets for competition. The net effect of such competition, especially at the retail level, would be much greater emphasis on electricity prices and less emphasis on energy services. Such an outcome would force a sharp reduction in the scale of DSM programs that are funded by customers in general. Instead, utilities could run only DSM programs for which participating customers were willing to pay the full costs.

The second force is increased concern about environmental quality and global warming. Because utilities are major contributors to U.S. carbon dioxide emissions, the Administration's Climate Change Action Plan calls on utilities to reduce such emissions. DSM programs are one key way to do that and, in the process, to cut customer electric bills and improve economic productivity.

This report discusses the forms of competition and how they might affect DSM programs. It examines the important roles that state regulatory commissions could play to affect retail competition and utility DSM programs. Commissions could set exit or reentry fees for customers that want to buy electricity from an entity other than the local utility. Or they could "tax" the use of the local distribution system to discourage uneconomic wheeling and to pay for DSM programs.

The report considers the effects of DSM programs on retail electricity prices and how utilities might redesign their DSM programs for a more competitive environment. Although my crystal ball is no better than anyone else's, I offer my view of the future for utility DSM programs:

They will focus more on customer service and less on the system-resource benefits. 
- The resource benefits will emphasize capacity reductions more and energy savings less. This shift will occur as utilities seek to minimize the lost revenues associated with DSM.

- From a resource perspective, DSM will become more cost-effective as utilities identify better ways to deliver DSM services at lower cost.

- Inter- and intraclass transfers will be reduced as utilities increasingly seek to have individual customers pay for their own DSM services.

In summary, while DSM programs in the future may be different from what they are today in both design and purpose, they will continue to be important. They will be important to utilities as powerful marketing tools, and they will be important to society because of their environmental and economic-productivity benefits. 


\section{LIST OF ACRONYMS}

$\mathrm{BP}$

$\mathrm{C} / \mathrm{I}$

DSM

FERC

IPP

MBTA

MECO

ORNL

PECO

PUC

RG\&E

RIM

TRC

T\&D
Bonus payment approach

Commercial and industrial customers

Demand-side management

Federal Energy Regulatory Commission

Independent power producer

Massachusetts Bay Transportation Authority

Massachusetts Electric Company

Oak Ridge National Laboratory

Philadelphia Electric Company

Public utility commission

Rochester Gas \& Electric Corporation

Rate impact measure

Total resource cost

Transmission and distribution 


\section{INTRODUCTION}

Although there is widespread agreement that the electric-utility business is becoming much more competitive, there is little consensus on what that implies for utility demand-side management (DSM) programs. Some groups believe that competition means the demise of such utility efforts to affect the amount and timing of customer electricity use. Often, these groups have traditionally opposed utility programs because they believe utilities should focus solely on production and delivery of electricity ( $\mathrm{kW}$ and $\mathrm{kWh}$ ) rather than electricity services and because they oppose the use of ratepayer funds to pay for efficiency improvements (and bill reductions) for DSM-program participants. These groups argue that the markets for energy efficiency are efficient and require no government or utility intervention (Sutherland 1991).

Other groups believe that DSM programs will be a key feature of the competitive landscape. They believe that utilities will, as part of their efforts to be more customer driven, emphasize the customer-service aspects of DSM programs. Often, these are the same groups that have long favored DSM programs because of their broad social benefits, both economic and environmental. These groups believe that serious market failures characterize energy-efficiency markets, which amply justify utility DSM programs (Levine et al. 1994).

This report examines possible futures for utility DSM programs. The report is part of a larger project that ORNL is conducting for the U.S. Department of Energy on the role of integrated resource planning for the utility of the future (Tonn and Schaffhauser 1994).

I am not so bold as to predict what that future will be. But I do identify the various forms of competition taking place and likely to occur in the industry, the potential role of PUCs in shaping those competitive forces, and various ways that utilities can modify their DSM programs to adapt to an unfolding future. Thus, this report provides a structure for thinking about the role of DSM in a more competitive utility environment. Although the report does not resolve these issues, I hope it will provoke further thought and discussion on the issues raised here. To that end, I encourage readers to call or write me with their comments on this report.*

The next section discusses the strengths and limitations of competitive vs regulated markets and the various forms of competition occurring in the electric utility industry. Section 3 discusses the role of state regulators in affecting retail competition. I argue that the future of utility DSM programs will be most affected by retail rather than wholesale competition; therefore, the policies that public utility commissions (PUCs) establish in this area will

\footnotetext{
${ }^{*}$ My address is Oak Ridge National Laboratory, P.U. Box 2008, Oak Ridge, TN 37831-6206. The phone number is (615) 574-6304, the fax number is 576-8745, and the E-mail address is hirstea@ornl.gov.
} 
substantially influence the scope and nature of future utility DSM programs. Section 4 discusses the possible effects of increased retail competition on DSM with particular emphasis on the role of electricity prices. Section 5 describes ways to design DSM programs to reduce their rate impacts, and Section 6 explains how DSM programs affect utility shareholders in today's regulated environment and how they would affect shareholders in a fully price-competitive environment. Section 7 presents my conclusions concerning the future of utility DSM. 


\section{BACKGROUND}

\section{COMPETITION VS REGULATION}

For decades, electric utilities have been regulated monopolies. State regulators and their utilities operate under a "regulatory compact." The state grants the utility a monopoly franchise; within a certain geographic area, the utility has the exclusive right to sell electricity. In return for that franchise, the utility has an obligation to provide service to any qualified customer that wants service.

Two factors supported the monopoly status. First, the generation, transmission, and distribution of electricity was believed to be a natural monopoly, such that provision of service by two or more entities would increase costs significantly. Second, the suppiy of electricity was considered a necessity, "clothed with the public interest" (California Public Utilities Commission 1993).

During the past several years, more and more questions have been raised about both utility regulation and its monopoly status. Are utilities still natural monopolies? Is state regulation continuing to serve the broad public interest? Might customers be better served by companies that had to compete with each other? How can small electricity consumers, for whom competition may offer few benefits, be protected? How might a competitive electricutility industry best meet environmental-protection goals?

Competition is increasingly discussed these days as a way to deal with a variety of problems. Several industries, including telecommunications, banking, airlines, and natural gas have been or are in the process of being deregulated and made more competitive. The pros and cons of meeting society's wants and needs by competition vs regulation vs managed competition are shaped largely by individual values. Those who believe that free markets work best tend to oppose government regulation because such regulations restrict individual freedom and impose inefficiencies on the economy. Those who believe that government programs can work favor government oversight because markets may yield outcomes that are inequitable and inconsistent with society's long-run objectives.

Although competition offers many benefits, it may also create some problems (Table 1). On the plus side, competition stimulates the introduction of new products and services and the demise of products and services that no longer meet customer needs. Although nothing inherent in competition favors the short-term over the long-term, competitive markets appear to price outputs to optimize short-term economic efficiency. On the other hand, societal values, such as environmental quality, long-term conservation of norirenewable resources, research to develop 
new energy sources, and equity concerns (e.g., protection of low-income households), are largely ignored in a competitive environment.

Regulation, on the other hand, can protect these broader societal interests. However, it does so at the cost of timely and efficient decision making. Consider the complexity, expense, and amount of time required to reach decisions at state regulatory commissions. Also, whether regulatory decisions truly reflect customer interests is often unclear. If certain interests "capture" the regulators, their decisions may not benefit customers broadly.

Table 1. Characteristics of competitive vs regulated markets

\begin{tabular}{lll}
\hline Issue & Competition & Regulation \\
\hline Time focus & Short-term & Long-term \\
Efficiency & $\begin{array}{l}\text { Economic (low cost, high } \\
\text { value) }\end{array}$ & $\begin{array}{l}\text { Societal (economic, } \\
\text { environment, equity) }\end{array}$ \\
$\begin{array}{lll}\text { Products/services } & \text { Many } & \text { Few } \\
\text { Price differentiation } & \text { Substantial } & \text { Limited to a few customer } \\
\text { classes }\end{array}$ \\
$\begin{array}{ll}\text { Recognition of differences } \\
\text { among customers }\end{array}$ & Yes & No \\
Decision making & Fast & Slow, litigated \\
\hline
\end{tabular}

Because of the limitations in competitive markets, all markets are bound by government or industry rules and procedures. As Reich (1991) noted:

The idea of a "free market" apart from the laws and political decisions that create it is pure fantasy anyway. The market was not created by God on any of the first six days (at least, not directly), nor is it maintained by divine will. It is a human artifact, the shifting sum of a set of judgments about individual rights and responsibilities. ...

... In modern nations, government is the principal agency by which the society deliberates, defines, and enforces the norms that organize the market. Judges and legislators, as well as government executives and administrators, endlessly alter and adapt the rules of the game-usually tacitly, often 
unintentionally, always under the watchful eye and sometimes under the guiding hand of interests with clear stakes in the outcomes of particular decisions. To the extent that rhetoric frames the issue as one grand choice between government and market, it befogs our view of the series of smaller choices about an endless set of alternative ways to structure the rules of ownership and exchange.

We will return to Reich's point about the role of government in establishing, maintaining, and conditioning markets later in the discussion of retail competition.

\section{FORMS OF COMPETITION IN THE ELECTRIC-UTILITY INDUSTRY}

The second background point concerns the forms of competition taking place in the utility industry today (Fig. 1). The Public Utility Regulatory Policies Act (U.S. Congress 1978) helped to create new nonutility companies that build and operate power plants. The Energy Policy Act of 1992 (U.S. Congress 1992) furthered that process by creating a class of generation companies exempt from the details of state and federal regulation. Thus, competition at the production end already exists.

If existing utilities are able to design, build, and operate power plants at costs below those of independent power producers (IPPs), then utilities may continue to be major players on the generation side. On the other hand, if the IPPs are more efficient and can build and operate power plants more cheaply and as reliably as today's utilities, then the utility role in generation will decline over time (assuming that utilities do not unfairly control access to transmission). Even here, the utility role is likely to be important in life-extension and repowering of existing power plants.

Transmission and distribution (T\&D; the wires) are natural monopolies. However, tough questions remain about what parties should operate and control today's system and build new systems. The Energy Policy Act recognized the importance of transmission access to making generation truly competitive. It gave the Federal Energy Regulatory Commission (FERC) the authority to order a transmission-owning utility to provide access to another party wanting to move electricity from a power plant to a wholesale customer. But much is unresolved concerning access to, pricing of, and expansion of transmission services.

To illustrate, FERC can order a utility to construct new transmission facilities to meet the needs of another party. However, state siting and regulatory authorities determine whether and when those facilities are actually built. Resolving this potential state/federal jurisdictional issue may be difficult.

Utilities might continue to dominate transmission markets, perhaps through the creation of regional transmission groups. Alternatively, regional entities (analogous to natural-gas pipelines) might arise whose sole function is to build and operate the T\&D systems. Hogan (1993) suggests splitting the transmission monopoly into two parts. The first, which he calls Gridco, would be responsible for the construction, operation, and maintenance of the 
transmission system. The second, which he calls Poolco, would manage the minute-by-minute dispatch of power plants and use of the transmission grid to transport power from generating units to load centers.

Small modular power plants (diesel generators, small combustion turbines, fuel cells, and photovoltaics) may become more cost-effective. If that happens, generating units can be located close to load centers, reducing the need for transmission of bulk power supplies. Although transmission would remain a monopoly, its importance would diminish in this scenario.

Although transmission is likely to be regulated primarily by FERC, state PUCs will retain regulatory control over distribution. Therefore, PUCs could have a substantial effect on the extent and nature of retail competition. Such competition, probably the most controversial element of the debates on the future of the utility industry, involves competition for retail customers among:

- Alternative fuels (e.g., switching from electricity to natural gas for certain end uses or industrial use of new electrotechnologies);

- Customer cogeneration or self-generation;

- Actions taken by customers, either on their own or with assistance from energy-service companies, to reduce peak demands and electricity use (thereby cutting electricity bills);

- Utilities seeking to encourage large customers to move from one local service area to another (utility to utility competition); and

- Alternative suppliers of electricity (i.e., retail wheeling).

The first four forms of retail competition already exist, although to varying degrees around the country. To the extent that customers believe they can meet their energy-service needs better and less expensively without the local utility, they can switch fuels, cogenerate or self-generate to meet their own electric needs, adopt energy-efficiency measures to reduce their electric bills, or move outside the local utility's service area. Whether customers take such actions depends, in part, on the level of retail electricity prices relative to the costs of these alternatives.

Retail wheeling (under which end users are free to choose their electricity suppliers) engenders the loudest and strongest debates, probably because of its effects on the traditional regulated monopoly franchise. If regulators allow retail customers to choose their electricity supplier, implicitly at least, they are taking away the local utility's franchise. In return, the local utility would (or at least should) no longer have any obligation to serve.

Proponents of retail wheeling believe it is crucial for customers, especially large industrials, to be free to choose their own electricity supplier (Hughes 1993). Absent such 
freedom, they will be unable to compete effectively in international markets, and local utilities will not be forced to improve efficiency.

Opponents believe that retail wheeling will lower costs only for large customers at the expense of utility shareholders and the remaining residential and commercial (core) customers (Cavanagh 1994). In addition to their worry about stranded investment, retail-wheeling opponents are concerned about the loss of the environmental benefits of DSM and renewables and the elimination of the utility's role as a portfolio manager on behalf of all retail customers.

Figure 1 shows several possible outcomes for competition at each of the three levels discussed here: generation, $T \& D$, and retail. Different combinations from each column, in a mix-and-match mocie, seem feasible.

To the extent that competition at the wholesale level lowers the costs of electricity production, the avoided costs against which DSM must compete will go down. Therefore, less DSM will be cost-effective. During much of the 1970s and 1980s, long-run marginal costs were above average costs. Thus, consumers faced price signals that, on average, encouraged them to use more electricity than was economically efficient. To the extent that long-run costs are now below average costs (and average rates), price signals encourage consumers to overinvest in energy efficiency. This change in the relationship between long-run marginal and average costs weakens the rationale for utility DSM programs. However, many important nonprice barriers to customer adoption of energy-efficiency measures remain, barriers that utilities can help overcome (Levine et al. 1994).

Under one scenario, at the retail level the franchise monopoly will hold, and today's utilities will continue to serve most of their existing customers, retaining the obligation to serve in return for which they retain their monopoly rights (top right box in Fig. 1). Only a few large industrials cogenerate, self-generate, or work out special deals that allow them to leave the system.

At the other end of the retail-competition spectrum, the franchise monopoly no longer exists (bottom right box in Fig. 1). All customers are free to choose their own supplier. Several utilities, as well as independent brokers, vie for retail customers. Brokers, who may own only telephones, computers, modems, and faxes, make "deals" in which they aggregate retail customers and purchase power from a combination of suppliers and arrange for T\&D delivery of that power to customers (Bretz 1994).

If the first retail scenario prevails, the effects on utility DSM programs are likely to be minimal. On the other hand, if there is considerable competition for end-use customers, utility DSM programs may change dramatically. In particular, utilities will no longer be able to charge all customers for the costs of these programs because prices will be set in a competitive market and not in a regulatory proceeding. Utilities will (1) either charge participating customers for their DSM services or (2) be able to spread the costs of DSM programs across only the remaining core customers. Therefore, utilities will run fewer programs that offer rebates to 
customers that install energy-efficient equipment; such programs will be aimed only at core customers. Instead, utilities will sell information, contracting services, measures and their installation, and performance guarantees to those customers choosing to buy these DSM services. And the emerging brokers may also offer DSM services to retail customers through energyservice companies.

I believe that the future of utility DSM programs is largely independent of the extent and form of competition at either the generation or transmission levels, although its success will depend on the costs of generation and transmission. Utility DSM programs are likely to be affected primarily by competition at the retail level.

GENERATION TRANSMISSION \& DISTRIBUTION

Utilities
dominate

IPPs build new units; utilities run existing units

$$
\begin{aligned}
& \text { Utilities } \\
& \text { own no } \\
& \text { generation }
\end{aligned}
$$

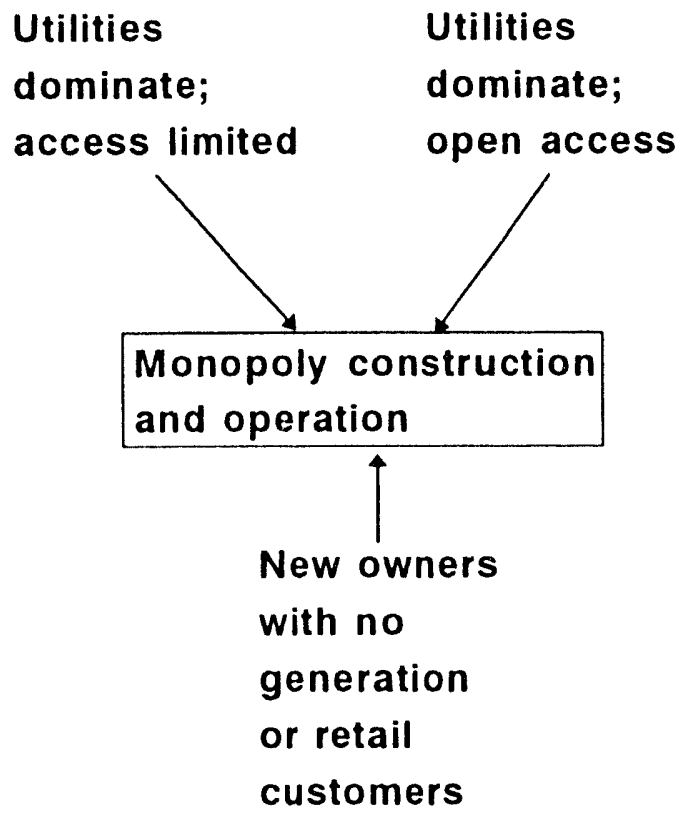

RETAIL

Franchise monopoly and obligation to serve intact

Monopoly largely intact; some wheeling

Lots of competition for retail customers

Fig. 1. The forms that competition might take in generation, transmission and distribution, and retail services in the electric-utility industry. 


\section{STATE REGULATION OF RETAIL COMPETITION}

It seems likely that FERC will play a stronger role than the state PUCs in shaping wholesale competition. But at the retail level, state PUCs are likely to be much more influential than FERC (Table 2), consistent with the role of government espoused by Reich above. Commissions may choose to shape the extent, pace, and beneficiaries of competition for retail electricity customers for three reasons.

Table 2. Possible PUC rules to structure retail wheeling

Define core vs noncore customers

Set terms and conditions for noncore customers

- Exit fee

- Reentry fee

- Advance notice to exit or reenter

- T\&D wheeling charge

- Prices for other services (e.g., backup, power quality)

First, it may be economically inefficient to allow customers to arbitrarily select their electricity suppliers. This situation could occur if the utility's retail prices do not fully reflect the costs of providing services to some customers and these customers then choose other options (e.g., cogeneration) that reduce their costs but not the overall costs to society.

Second, it may be inequitable to allow such freedom. Customers that leave the utility system may create a "stranded investment" problem for the remaining customers and the utility's shareholders. Although this is primarily a transition problem, the amount of money at stake (as much as 10 to $20 \%$ of utility assets) is large enough to warrant careful attention."

Third, in a fully competitive retail market, utilities may want to drop the societal functions they currently furnish, including provision of demand-side services to customers. For

\footnotetext{
* One way to address this problem would he to allow utilities to write up their T\&D assets by the same amount that they write down their generating assets. This procedure would rationalize prices for both generation and T\&D and keep utility shareholders and core customers whole.
} 
various reasons, including environmental quality, economic productivity, and the provision of capacity and energy resources, commissions may want to be sure that such services are still available to customers.

Discussing the steps that PUCs could take to shape retail competition is important because these actions could have major effects on future utility DSM programs. In addition, a recent survey found that PUCs are not yet ready to deal with increased retail competition, lacking policies that require, encourage, permit, discourage, or prohibit retail wheeling ( $R$. J. Rudden Associates and Fitch Investors Service 1993). According to that survey, only $19 \%$ of the responding PUCs had policies in place to deal with recovery of stranded investment, and only $31 \%$ had policies to protect core customers from higher prices.

PUCs could decide which customers are eligible to become noncore. In some jurisdictions, PUCs have set minimum size limits for noncore customers of natural-gas utilities. PUC decisions on size might reflect their judgments on which customers are most able to negotiate well with suppliers and which customers can most benefit from that choice. On both scores, large industrial customers may be those most likely to be able to select their own electricity suppliers.

Although the California PUC began by setting minimum size limits for noncore customers of the local gas utilities, these limits soon dropped and were then replaced by unbundled rates. These rates covered separately the commodity, capacity, transportation, and storage costs of delivering gas to customers. On the electric side, Commissions could establish separate rate schedules for each utility service, including energy, capacity, transmission service, distribution service, reserve margin, power-factor correction, power quality, and so on. A recent conference on electricity pricing contained many papers dealing with innovative ways to unbundle prices (Electric Power Research Institute 1994).

For potential noncore customers, PUCs could establish requirements for exit and/or reentry. To illustrate, the PUC could require exiting customers to reimburse the utility (i.e., remaining customers) for the undepreciated investments made by the utility on behalf of the departing customer. Or the Commission could allow the utility to charge the departing customer the difference between the revenues that customer would likely pay the utility over a set number of future years and the utility's year-to-year avoided costs (Fig. 2). If the utility has considerable excess capacity and therefore low avoided costs for several years, the exit fee could be substantial. On the other hand, if the utility faced rapid load growth and needed capacity soon, the exit fee could be much sinaller or even zero. In such a case, the departing customer would lower long-term costs for the remaining customers.

Such a requirement would have two powerful effects. First, it would ensure that neither utility shareholders nor remaining customers would have to pay for "stranded" investment. Second, the charge might discourage customers from pursuing uneconomic retail-wheeling options. 
PRICE AND COST (c/kWh)

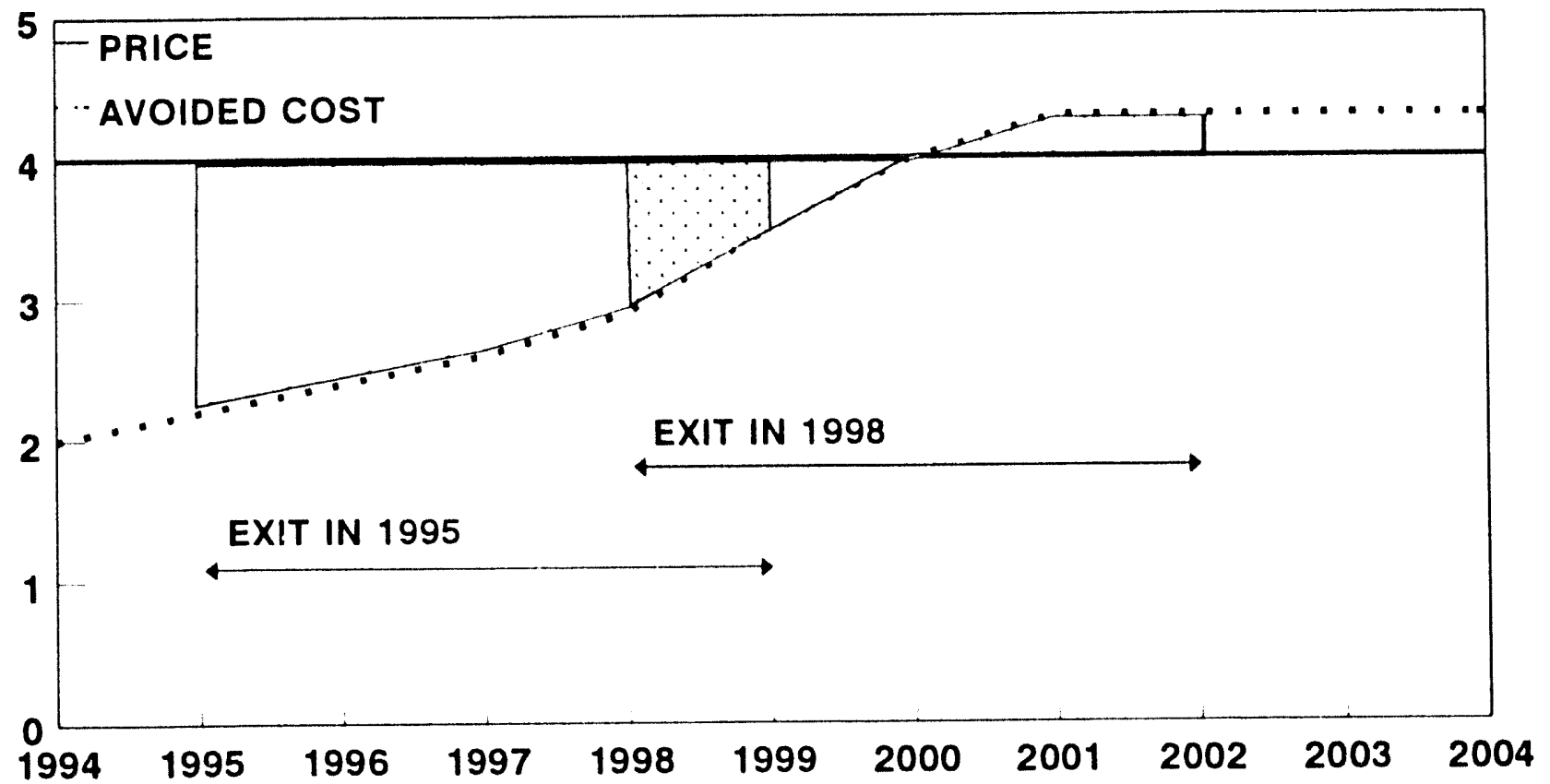

Fig. 2. Schematic showing exit fees for large customers that leave the local utility's system in (1) 1995 or (2) in 1998. In each case, the exiting customer pays the utility the net present worth of the difference bet ween avoided cost and retail rate for five years.

A case before FERC provides precedent, although at the transmission rather than distribution level, for such an exit fee. Philadelphia Electric Company (PECO) filed with FERC an amendment to an existing agreement with Conowingo Power, a PECO wholesale customer (Corcoran 1994a). The amendment would add a termination charge if Conowingo stops or reduces its purchases from PECO. The termination charge would consist of a lump sum equal to the present value of the demand charges that PECO would otherwise have received from Conowingo through 2004. By that time, PECO would be fully utilizing its existing generating capacity.

Alternatively, commissions could require noncore customers to provide advance notice if they wish to return to core (full service) status; TransAlta, Canada's largest investor-owned utility proposed just such a five-year advance-notice requirement (Huntingford and Nelson 1993).

Considerable work remains to determine the economic rationale for either exit or reentry fees. In particular, commissions need to establish the relationship between such fees and the utility's current retail tariff and its short- and long-run marginal costs. 
Commissions might impose on noncore customers a distribution-system fee, the proceeds of which could be used to pay for the functions that the utility undertakes on behalf of society in general and certain core customers in particular. (FERC could impose a similar fee on transmission services.) The fee, set on a $c / k W h$ or $\$ / k W$ basis, could be justified in different ways. One approach would set the fee equal to the difference between the utility's current retail rate and its marginal supply cost (Moskovitz et al. 1993). Setting the fee in this way would ensure that retail customers do not make uneconomic purchase decisions.

The fees collected in this way, beyond the utility's direct costs for building and operating its distribution system, could be used for various social purposes. These purposes include:

- lifeline rates for low-income customers,

- low-income weatherization,

- acquisition of renewable resources that are not yet cost-effective,

- acquisition of DSM resources that provide broad economic and environmental benefits but that raise prices, and

- research and development on advanced energy-supply and DSM technoiogies.

These functions might be especially important to implement the carbon-dioxide reductions called for by the national Climare Change Action Plan.

Massachusetts Electric Company (MECO) filed a request along these lines with FERC. (Corcoran 1994b). The case involves the Massachusetts Bay Transportation Authority (MBTA), which until recently was a MECO customer but now is requesting only wheeling services from MECO. MECO's request includes, in addition to the usual charges for transmission and distribution services, a stranded-investment charge based on its power-supply costs. MECO claims that it arranged for power supplies on the expectation that the MBTA would remain a customer. The proposed stranded-investment charge will automatically be reduced to reflect actual load growth that, presumably, will use the capacity made excess by the MBTA's departure from the MECO system.

Commissions may want to expand utility flexibility in negotiating prices with the larger customers that have choices. Commissions can require utilities to offer energy-efficiency services to such customers in negotiating lower prices and costs. For example, Southern California Edison's (1993) self-generation deferral rate is intended to prevent uneconomic bypass. It permits the utility to offer large customers a rate lower than its standard industrial tariff if the customer can "demonstrate serious intent and feasibility to self-generate." The PUC guidelines for this rate require the utility to offer a conservation alternative to the special rate. This alternative involves utility financing of an investment in energy-efficient equipment at the customer's facility. 
To illustrate, Southern California Edison recently agreed to install various measures at the Eisenhower Medical Center under the self-generation deferral rate. The measures include efficient chillers, a hydronic ecunumizer, and high-efficiency lamps and ballasts. These measures will cost about $\$ 600,000$ and should reduce utility bills by about $\$ 900,000 /$ year.

Finally, PUCs will likely define the utility's "obligation to serve" differently for core and noncore customers. The utility's obligations to provide reserve margin, power quality, and other services to noncore customers may be minimal or zero. On the other hand, PUCs may require utilities to offer backup services to such customers, the pricing of which would affect the attractiveness of retail wheeling.

Whether any of these mechanisms are legal and politically feasible will vary from state to state. Large industrial customers (those most likely to benefit from easy access to other suppliers) will argue strongly against such "obstacles" to competition. In addition, substantial practical problems may arise in designing equitable mechanisms. For example, what criteria would be used to decide which customers would pay an exit fee or a reentry fee? Would it be based on size and, if so, on annual revenue, sales, or peak demand? Could the exit fee be applied to industrial customers that physically leave the utility's service area or only to those customers that switch suppliers? Would the reentry fee be applied to new customers moving into the service area or only to customers that had earlier been served by the local utility? If the latter, would the charge be a function of the number of years that the customer had been off the system?

A 1993 New York Public Service Commission decision provides precedent for the kinds of requirements discussed above (Kelleher and Wood 1994). The Commission approved an industrial Subscription Option program that allows large commercial and industrial customers to "opt out" of the standard DSM programs offered by Niagara Mohawk. Customers that chose to opt out are no longer eligible for participation in these programs and no longer have to pay for part of those DSM-program costs. However, as a condition for opting out, the industrial customer has to pay for a detailed energy audit at its facility and provide that audit to Niagara Mohawk. (Initial results from these audits show average potential energy savings of $7 \%$ with a less-than-four-year payback.) The utility offers a shared-savings program to help these customers finance installation of measures recommended in the energy audit. This decision shows the feasibility of imposing DSM-related requirements on customers as a condition for certain treatment (e.g., access to retail wheeling).

The California PUC (1993), in its review of regulatory reforms, suggested four strategies for state regulation of electric utilities. Although much broader than my focus on retail competition, the PUC's strategies contain some of the same elements:

Limited reform, in which current cost-of-service regulation is retained, but rate cases are held every year, and most balancing accounts are eliminated. 
- Price-cap model, in which the regulatory compact remains, but the utilities gain considerable pricing flexibility, and the link between utility rates and costs is broken.

- Limited customer choice, in which a limited segment of customers is given access to competitive markets. The remaining (core) customers are served under traditional cost-ofservice regulation, but the utility's obligation to serve noncore customers is substantially reduced.

- Restructured utility industry, in which the regulated utilities divest themselves of all generating assets and become common-carrier transmission and distribution companies. Utilities no longer enjoy a monopoly retail franchise, but in return they no longer have an obligation to serve those customers that choose other suppliers.

The role of utility DSM programs would likely differ substantially across these four strategies. Under limited reform, such programs could continue with little change from today. Moving down the list, the programs would be progressively smaller and shift more of the costs to participating customers. 


\section{RETAIL COMPETITION, PRICES, AND DSM}

A key question concerning retail competition is the role of price. Will utilities and others compete for retail customers on the basis of unit price $(\mathrm{c} / \mathrm{kWh})$ alone? Do consumers view electricity as a homogeneous product for which price is paramount? Or do they view electricity as a service with many attributes? Although we do not now know the answers to these questions, it seems likely that customers differ, with some emphasizing price and some emphasizing service.

Although much of the rhetoric suggests that price will dominate, it is helpful to consider the role that price plays in other competitive markets. Consider the extent to which people buy cars on the basis of unit price (\$/pound), rather than on the basis of total cost, comfort, reliability, and other attributes. Similarly, do people go to movies on the basis of their unit cost in $\mathrm{c} / \mathrm{minute}$; do they buy books on the basis of $\mathrm{c} /$ page? These examples suggest that consumers will choose utilities on the basis of price, cost (the utility bill, which is the product of price and quantity), convenience, reliability, safety, and various consumer services, such as energy efficiency.

Regardless of whether price is the only factor on which suppliers will compete, price will surely be important. Industrial groups are aggressively comparing industrial electricity prices of their utility with those of surrounding utilities, and Wall Street financial advisers are doing the same. For example, the Tennessee Valley Industrial Committee, an association of large industrial customers of the Tennessee Valley Authority, commissioned a study to compare TVA industrial rates with those of other southeastern utilities (Drazen-Brubaker \& Associates 1993). Rates varied by a factor of two, from 2.6 to $5.5 \mathrm{c} / \mathrm{kWh}$. (Utilities with high retail rates might use DSM as a way to compete with lower-cost providers.)

Regardless of whether customers focus on price, many utilities are acting as if they do. This means that utilities will look for more and more ways to control costs. Indeed, much of the recent downsizing at utilities is driven by management interest in lowering costs to become more competitive.

Just how important is DSM to a utility's prices? Answering this question requires information on the utility's DSM-program costs, the supply costs the utility would avoid because of the energy and demand reductions caused by the DSM programs, and the lost revenues caused by DSM-induced electricity savings. As explained by Hirst and Blank (1993), improvements in customer energy efficiency that lower sales also cut utility revenues. While utility costs go down also, the short-term cost reductions (primarily for fuel) are much less than the revenue 
reductions. In the long term, if DSM programs defer construction of new resources, costs may decline more than revenues do.

This difference between revenue and short-term cost reductions, called net lost revenues, is the fixed-cost component of electricity price, typically 50 to $75 \%$ of the total cost of electricity. In many states, utilities recover these lost revenues from their customers. In other states, utility shareholders bear these losses until the next rate case.

In general, the effects of DSM on electricity price are small, on the order of a few percent (Faruqui and Chamberlin 199.3). A forthcoming study, based on 66 data points, finds that the median price increase caused by utility DSM programs is 2.7\% (Pye and Nadel 1994). Even in New York, which has aggressive utility DSM programs and low avoided costs, average electricity prices in the year 2000 will be only $6 \%$ higher than they would be without DSM programs (Gallagher 1994).

Cost overruns at nuclear plants and excess capacity are much more important factors in increasing electricity prices. On the other hand, the costs of these plants are sunk, whereas DSM program costs are at the margin and therefore discretionary. However, tree trimming along distribution lines to reduce the frequency of outages, maintaining inventories of transformers and cable to reduce the duration of outages, and providing telephone customer-assistance centers to improve customer service all cost money and do not increase electricity sales. Thus, these activities, like DSM, raise short-term prices. It is unclear whether these expenditures are receiving the same scrutiny that DSM-program costs are.

If electricity prices were set equal to short-term variable costs, then the lost-revenue problem would disappear. However, because short-term costs are generally below long-term marginal costs, basing prices on short-term costs would send misleading signals to customers, encouraging them to ignore the long-term consequences of their energy-related decisions. In particular, such pricing would lead them to underinvest in energy-efficiency measures. On the other hand, if nonprice market barriers are the primary obstacle to customer adoption of costeffective energy-efficiency measures, setting prices equal to short-term marginal costs and having utilities offer DSM programs may be the preferred route to achieving the benefits of improved energy efficiency. Also, pricing at short-term marginal cost is what a competitive power market is likely to yield (Hogan 199.3).

To explore the effects of utility DSM programs on retail electricity prices, consider a program that runs from 1995 through 1997. The utility pays the full cost of installing DSM measures. The program cuts overall demand by $1 \%$ as of 1998 and has a benefit/cost ratio (based on the total resource cost test) of 1.6. If program costs are ratebased, rather than expensed, net-lost revenues might account for about one-third of the average price increase (Fig. 3). 
$\%$ INCREASE IN ELECTRICITY PRICE

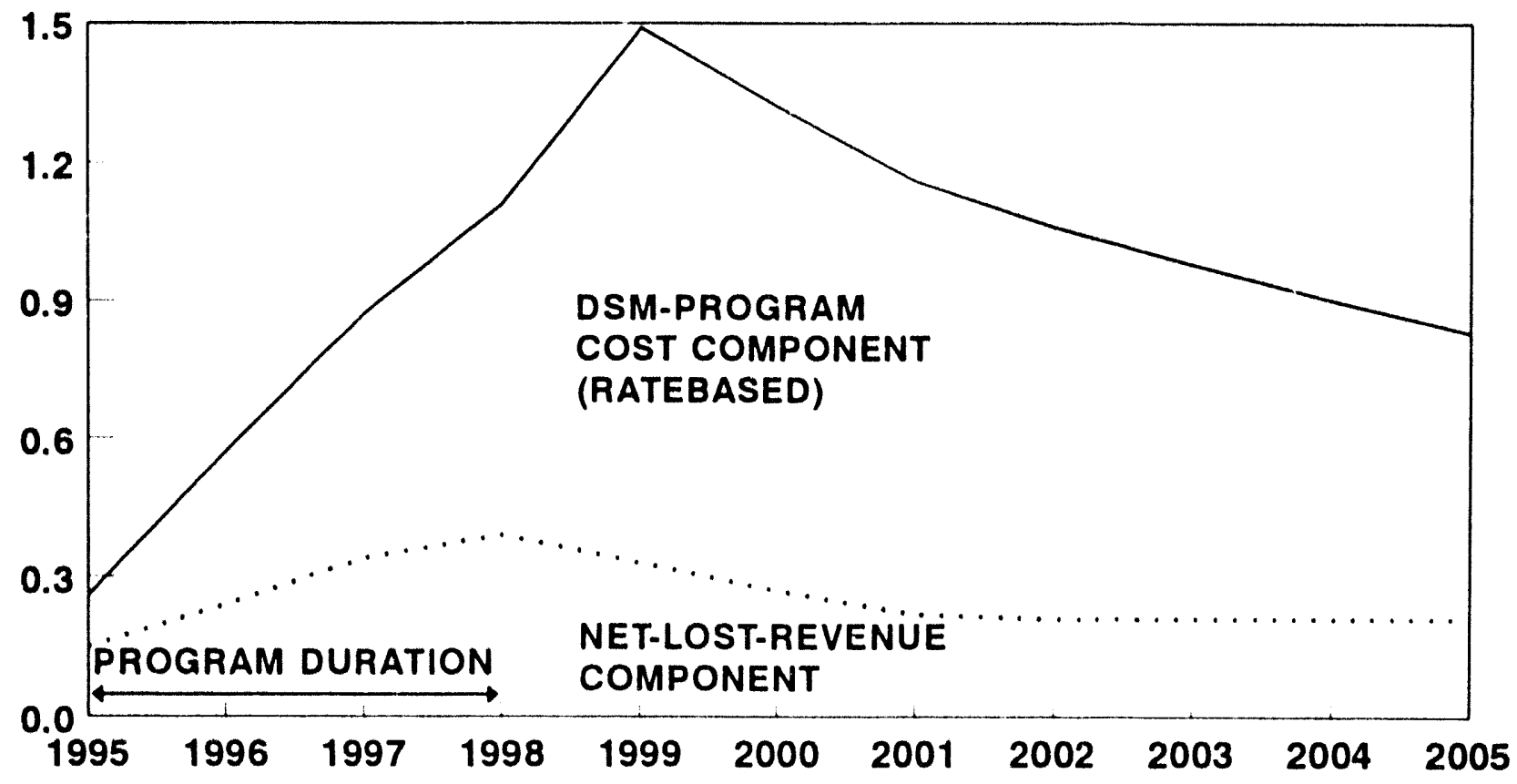

Fig. 3. Effects of a hypothetical utility DSM program on electricity prices, showing the relative effects of program costs and lost revenues.

If short-term variable costs are lower than in this example, the lost-revenue component and total price impact would be greater. For example, Public Service Company of Colorado (1993) proposed a set of DSM programs that provide substantial system benefits. Over the 20year analysis period, however, these programs are likely to raise electricity prices by $3 \%$. Netlost revenues contribute almost $60 \%$ to this price increase, with program costs accounting for the other $40 \%$. Thus, the rate impacts of DSM programs depend both on program costs and on the differences over time between avoided costs and retail prices.

This discussion suggests that utilities in the future are likely to design and operate their DSM programs with greater attention to the rate-impact measure (RIM) and less attention to the total-resource-cost (TRC) test (California Commissions 1987). The two tests differ primarily in their treatment of lost revenues. The TRC test, which includes both participating and nonparticipating customers, ignores lost revenues. The RIM test, which focuses on nonparticipants, treats lost revenues as a cost. 


\section{DESIGNING DSM PROGRAMS TO LOWER RATE IMPACTS}

The more market research utilities conduct (to better understand what customers want and what utilities can profitably provide), the more successful their DSM programs will be. Success includes increased participation rates and lower utility costs. If utilities can better understand their customers, they may be able to offer DSM programs that both improve customer service and provide the resource benefits of "traditional" DSM programs. As Stone (1993) notes, "Utilities that practice DSM aggressively have a sophisticated understanding of critical end-use technologies, of customers' decision processes and the factors that influence them, and of how their own cost [and price] structures position them competitively."

It will be interesting to see whether utilities use the opportunities provided by current regulation (i.e., mandates to run DSM programs that are paid for by all customers) to develop the marketing skills they need to deliver DSM in a competitive environment. In particular, will utilities be able to overcome their tradition of long-leadtime projects that required decision making based on a hierarchical structure and careful analysis? Or will they be able to shift to the rapid, flexible, decentralized decision making needed to market DSM programs to customers? An equally interesting issue is whether PUCs will allow utilities such flexibility in designing, running, and modifying their DSM programs.

A recent study suggests that some utilities, at least, are learning how to market skillfully to their customers (Keneipp et al. 1993). Pacific Gas \& Electric has corporate account managers who work closely with customers that spend more than $\$ 0.5$ million/year on PG\&E utility bills. Each manager has 25 to 30 such accounts and has frequent personal contact with them. Similarly, Wisconsin Electric has an account executive who works with "chains" (e.g., supermarkets, department stores, discount stores, and fast-food stores) for which decisions may be made at the regional or national level. These skills are important because the largest potential savings are in the commercial/industrial $(\mathrm{C} / \mathrm{I})$ sector, and these customers are most at risk.

The keys to running successful DSM programs seem to be:

- Keep the program simple.

- Update the program to recognize changing market dynamics (e.g., that would allow use of a lower rebate), but do so only once a year.

- Work closely with trade allies (but remember that their interests may not match the utilities'). 
- Use financial incentives to motivate utility marketing staff.

- Train in-house and trade-ally staff on the program and its measures/technologies.

Learning how to market effectively will be increasingly important if utilities can no longer use rebates (paid for by customers in general) to entice customers to participate in DSM programs. On the contrary, utilities may have to sell DSM to customers and convince them that such services are worth their full cost.

Increasingly, utilities will unbundle their services so that each customer is offered (and purchases) an appropriate mix of $\mathrm{kWh}, \mathrm{kW}$, reliability, power quality, and DSM at an appropriate price. For those customers that focus on price, fewer services will likely be selected. Other customers may select DSM options if they are more concerned with bills than prices and if the value of these DSM services exceed their costs. Finally, utilities will increasingly use DSM as an alternative to price breaks.

Consider how a utility might respond to the "threat" of an industrial cogeneration project in a competitive environment. Traditionally, the utility might have (1) ignored the possibility and let the customer leave the system with no effort to retain that customer, (2) pointed out the complications and negative aspects of cogeneration in an effort to dissuade the customer from installing such a system, or (3) offered a discount rate to retain the customer.

In a more competitive environment, the utility might help analyze the economics of a cogeneration system. If the economics are attractive, the utility might of fer to build and operate the system on behalf of the customer. The utility might benefit from owning and operating this system if it costs less than the net-revenue losses associated with the customer's departure from the utility system. Also, building and operating cogeneration systems might provide new business opportunities for utilities.

Alternatively, the utility might offer DSM as a way to cut the customer's utility bill. For example, Rochester Gas \& Electric (RG\&E) convinced the University of Rochester not to install a 10-MW cogeneration system (Demand-Side Report 1994). The key to this change of heart was the utility's offer of an \$8-million program of energy-efficiency improvements. The university will pay about $\$ 6$ million, the utility (through an energy-service company) will pay about $\$ 2$ million, and the reduction in the university's utility bill should be about $\$ 2$ million/year. In return, the university agreed to stay on the RG\&E system for at least seven years. Southern California Edison's investment in efficiency improvements at the Eisenhower Medical Center, discussed earlier, is another example of this approach.

The likely key to success for DSM programs in the future will be increasing the participant contribution to program costs, thereby reducing the support for DSM from nonparticipating customers. Blank (1993) and Chamberlin, Herman, and Wikler (1993) suggest several possible ways to accomplish that objective. 
Blank proposed a novel way to pay for DSM programs that he called the bonus-payment (BP) approach. The twin purposes of this approach are to reduce the rate impacts of DSM programs and to retain high participation levels. The utility, under this system, would pay all the up-front costs of the energy-efficiency measures plus a cash bonus. Thus, participants have no out-of-pocket costs when the measures are installed. In return, the utility recovers program costs and perhaps net lost revenues through the participants' monthly utility bills.

Blank's method is similar to shared-savings schemes tried in the past. However, these approaches may reduce participation in the program relative to what would occur if the utility offered rebates to participating customers. Blank's innovation is to have the utility provide an up-front bonus that, implicitly, compensates participants for the inconvenience associated with participation. This bonus is intended to be so attractive that it more than offsets the subsequent customer repayment.

From an analytical perspective, Blank's method is appealing if customers use discount rates in assessing energy-efficiency alternatives that are higher than the utility's discount rate (typically, the weighted average cost of capital). ${ }^{*}$ If this condition applies, then customers gain the benefit of the bonus, which they value more highly than the (heavily discounted) monthly repayments. The utility, on the other hand, values the repayments more because of its lower discount rate.

Figures 4 and 5 compare the cash flows to participants and the utility, respectively, with traditional rebate programs and the BP approach. With a rebate, customers typically pay part of the cost of the DSM measures and their installation. On the other hand, customers keep all of the subsequent bill savings for themselves, as shown by the solid line in Fig. 4. With the BP approach, customers have a positive cash flow from the start; their subsequent monthly savings are much smaller because they are shared with the utility, as shown by the dotted line.

Figure 5 shows the cash flows from the two program designs for the utility. With the BP method, the utility's initial cost is higher, but its later revenues are also greater. Given the assumed differences in discount rates between participants and the utility (acting on behalf of customers as a whole), the bonus payment method should create a win-win situation.

${ }^{*}$ Considerable evidence exists that consumers do use (implicitly) higher discount rates in making energy-efficiency decisions than utilities use in making investment decisions (Ruderman, Levine, and McMahon 1987). 


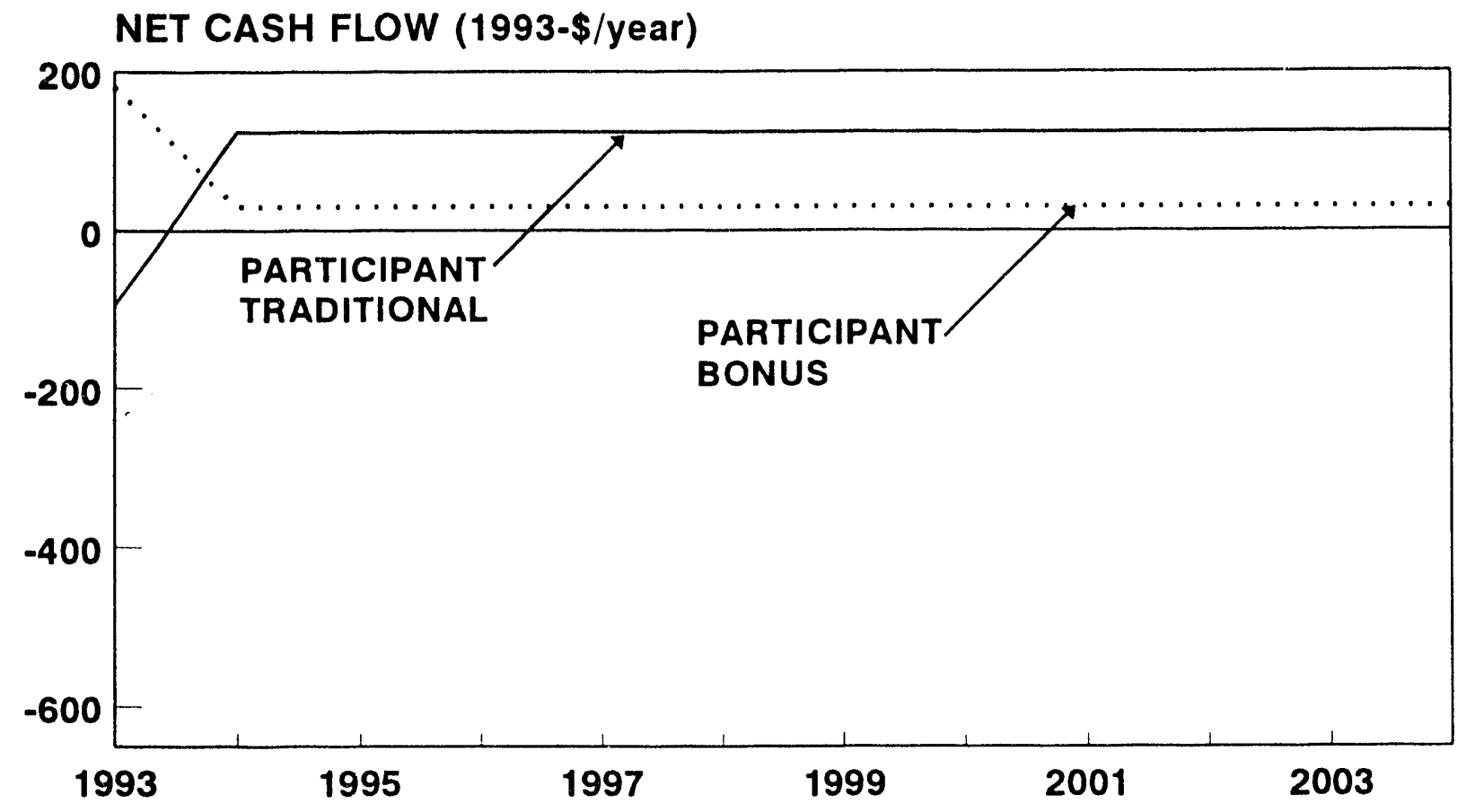

Fig. 4. Annual cash flows seen by DSM-program participants under rebate and bonus-payment program designs.

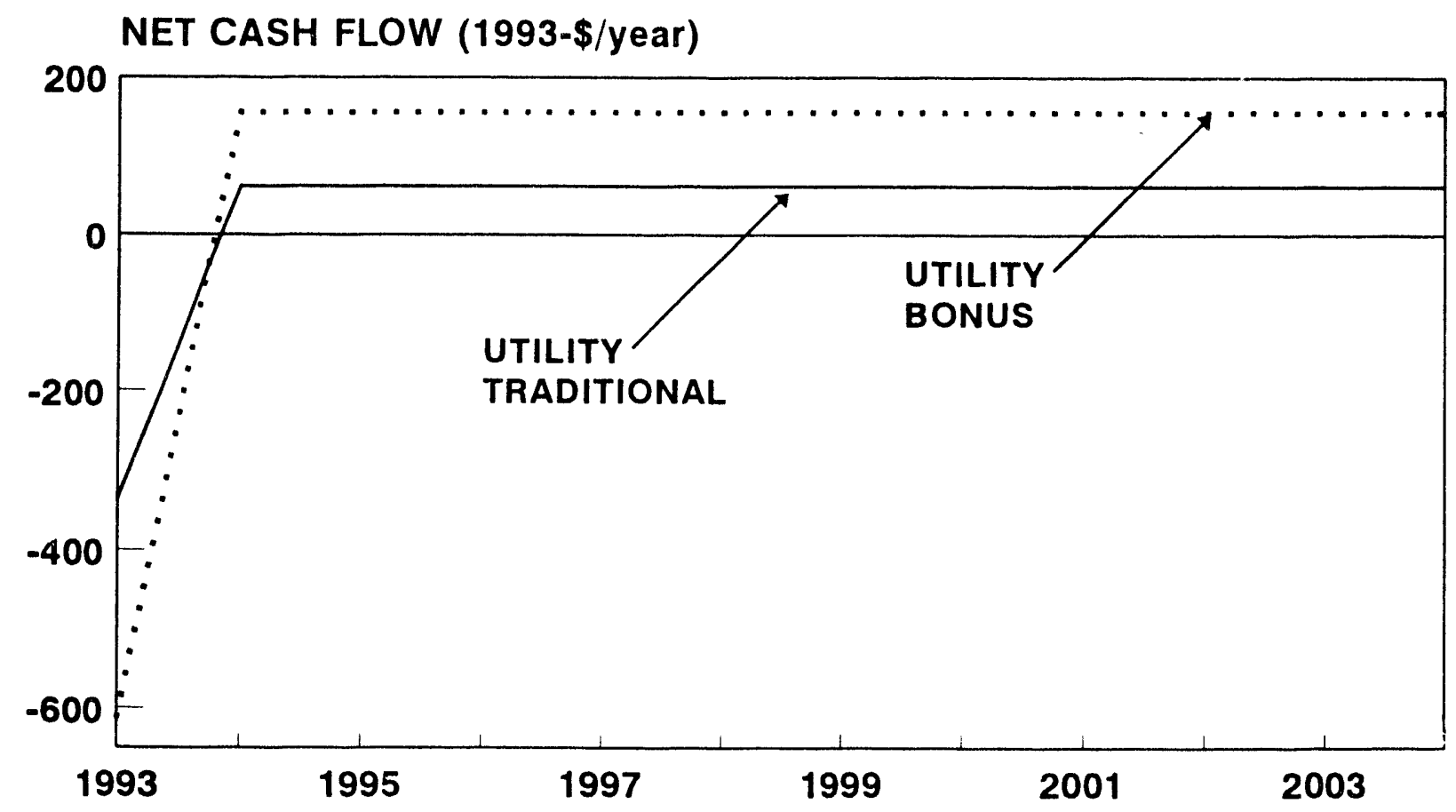

Fig. 5. Annual cash flows seen by a utility under rebate and bonus-payment program designs. 
Some utilities, including PacifiCorp and Southern California Edison, are moving to this model of DSM program. Although their programs do not include the up-front bonus that Blank recommends, both utilities provide turnkey services to participating customers in the commercial and industrial sectors. These services include analysis of energy-efficiency opportunities (including, in some cases, fuel-switching possibilities) and other productivity improvements; installation of measures; verification that the measures were installed and are operating properly (commissioning); and financing. In return, participating customers repay all the utility's costs, including interest payments, on their monthly utility bills (Hassan 1994).

Chamberlin, Herman, and Wikler (1993) suggest several ways to reduce the price increases normally associated with DSM programs. These possibilities include:

- Accept only those programs that pass the RIM test. This restriction will severely limit acceptance of programs that reduce electricity consumption, and focus DSM programs on reductions in peak demand.

- Accept programs primarily on the basis of the TRC test and

- Ensure that all customers have access to at least some DSM programs,

- Charge participants for energy services rather than for $\mathrm{kWh}$ and $\mathrm{kW}$ (similar to Blank's approach minus the up-front bonus payment), and

- Allocate DSM-program costs and lost revenues within each customer class.

- Accept a package of DSM programs that passes the RIM test and has the highest TRC benefit. This approach involves selection of programs that pass the RIM test plus enough of the programs with high TRC benefits so that there is no net effect on electricity prices.

- Use the TRC test for residential programs and the RIM test for programs aimed at the larger commercial and industrial customers, with each class paying only for its own programs. This approach makes sense if small customers are responsive primarily to bills and large customers respond most to prices.

The timing of DSM programs can have substantial effects on the costs a utility avoids and therefore on the programs' cost-effectiveness (Richer 1993). DSM programs designed and timed to defer construction of new generating capacity can mitigate or eliminate ate increases. Alternatively, running ambitious DSM programs when the utility's avoided costs are low relative to retail prices can exacerbate rate impacts. In addition, utilities could target DSM programs to

\footnotetext{
*PUCs may still want utilities to acquire "lost-opportunity" resources even if the utility's short-term avoided costs do not call for ambitious DSM programs. Lost opportunities are actions that are time sensitive, including the chance to improve energy efficiency in a new factory or during extensive remodeling of an office building. Failure to act at the right time means that the potential efficiency gains are lost or that they will be much more expensive to acquire later on.
} 
those geographic areas where investments in T\&D (as well as investments in generation) could be deferred, thus increasing the benefits of DSM programs.

On a more general level, utilities will need to understand, in much greater detail than they do today, what it costs to serve different groups of customers. The cost-of-service studies that utilities routinely conduct for rate cases will find new uses in utility marketing departments. Increasingly, these studies will include geographic disaggregation to reveal the large variations in avoided T\&D costs across a utility's service area.

Whether the utility expenses DSM-program costs or treats these costs as capital investments that are part of the ratebase affects the timing of electricity-price increases (Hirst 1992). Expensing programs causes short-term price hikes, whereas ratebasing spreads the price increases over the amortization period. In the long run, if DSM programs are running at roughly a constant level from year to year, the differences between expensing and ratebasing in their effects on retail prices are minor. On the one hand, because customers likely have higher discount rates than utilities do, ratebasing is preferred. On the other hand, ratebasing is more expensive because of income-tax effects.

To reduce program costs, utilities may move upstream of their retail customers and undertake market-transformation programs. In such programs, utilities work with retailers, wholesalers, and manufacturers in an effort to completely change the market. Such programs are likely to be much more cost-effective than are efforts aimed at individual customers because the utility deals with far fewer entities. For example, B.C. Hydro ran an industrial efficient-motors program that largely converted the market in British Columbia from inefficient to efficient motors in three years (Flanigan and Fleming 1993), primarily by working with distributors and manufacturers.

Although such market-transformation programs are likely to be very cost-effective from a broad societal perspective, the very reason for their success - utilities no longer have to deal with individual customers to promote DSM actions - argues against their use in a competitive environment. Why should utilities work with dealers and manufacturers when the benefits will flow to all retail consumers whether or not they purchase their electricity from the utility? This dichotomy between private and public interests argues for a strong PUC role to ensure that the benefits of market transformation are not lost in a retail-competitive world.

Utilities during the past few years shifted their DSM emphasis from the residential sector to the $\mathrm{C} / \mathrm{I}$ sector. They made this shift in recognition of the larger potentials for improving efficiency in the $\mathrm{C} / \mathrm{I}$ sectors and the greater cost-effectiveness of such programs. In particular, the transaction costs per $\mathrm{kWh}$ or $\mathrm{kW}$ saved can be much less than in the residential sector, because each commercial or industrial customer has much greater DSM potential than individual residential customers. Ironically, if retail wheeling becomes widespread and the large C/I customers leave the local utility, the utility may be left with only the less cost-effective DSM opportunities, those in the small-C/I and residential sectors. Here, too, PUCs may want to establish regulations to ensure that the most cost-effective DSM opportunities are captured. 
Utilities will have to find suitable niches (combinations of DSM products and services aimed at particular groups of customers) for their DSM activities. These niches might include new services not now widely available, such as building commissioning. They might include services that the utility currently provides for itself but not for customers, such as analysis of distribution transformers. And utilities might continue to offer many of the traditional DSN. products they have been offering, although packaged in ways that are more appealing to customers, including computerized home energy audits and commercial-lighting improvements.

High-efficiency transformers provide an interesting example of a service that utilities, perhaps uniquely, could provide their large industrial customers. Such transformers, those bought both by utilities and by large customers, can provide cost-effective savings, with paybacks ranging from 1.5 to 4 years. But "[v]ery few utilities treat distribution transformers as a DSM resource or actively help their customers to purchase more efficient models. Absent encouragement from utilities, end users typically overlook efficiency in their transformer purchasing policies, most often buying based solely on lowest first cost" (Howe 1993).

Utilities have unique access to detailed information on the electricity-use patterns of their customers. Utilities might be able to sell information services to their customers, based on these data. For example, utilities could disaggregate residential-customer electric bills to show the costs of operating various appliances. Surveys show that customers do not know how much electricity various end uses consume and would find such information useful (Hopkins, Paquette, and Sioshansi 1994). For large commercial customers, utilities could link real-time price signals with building-automation systems, allowing the building's heating, ventilating, and airconditioning control systems to respond to hour-by-hour changes in electricity prices. Such a service would benefit both the utility and the customer (Flood, Carmichael, and Vold 1994).

In the future, utility DSM programs are likely to focus more on costumer service, with less emphasis on providing capacity and energy resources to the utility. Utilities will explore, identify, and implement a much wider range of energy-efficiency and load-management programs than exist today as they work with different market segments among their customers. 


\section{POSSIBLE EFFECTS OF DSM ON UTILITY SHAREHOLDERS}

Utility shareholders may have very different views of DSM if traditional cost-of-service regulation gives way to substantial price competition. To see how shareholders fare, I use a simple financial model under development at ORNL (Hirst and Hadley 1994).

I assume a DSM program that operates for three years, from 1995 through 1997 , at the end of which it has reduced electric demand and sales by $1 \%$ at a cost to the utility of $\$ 2000 / \mathrm{kW}$ $(3.4 \mathrm{c} / \mathrm{kWh})$, yielding a TRC benefit/cost ratio of 1.6 . (This example uses the same program shown in Fig. 3.) Under traditional regulation, the PUC holds a rate case on January 1, 1998, with rates that go into effect that day. Thereafter, rate cases are held once every four years. Changes in return on equity are calculated over a 36-year period, including the 4 years of "construction" plus the 32 years of operation. If DSM-program costs are ratebased, shareholders earn a slightly higher return on equity ( 3 basis points) than if the utility did not run this DSM program (left half of Fig. 6). However, if the utility is not authorized to recover the net lost revenues associated with its DSM program from 1995 through 1997 (before the 1998 rate case), its overall return on equity is lower by 1 basis point than if it ran no DSM programs.

Consider an entirely different situation from the traditional regulatory regime. Assume that the utility operates in a fully price-competitive environment in which it can sell electricity at no more than an exogenously determined price. In this case, implementing the same 4-year DSM program cuts return on equity by about 30 basis points (right half of Fig. 6). Even if the utility can implement the DSM programs (i.e., provide the efficiency improvements and electricity savings) at no cost, shareholders still lose money (about 10 basis points). This loss occurs because the reduced revenues associated with the program-induced sales reduction is only partially offset by lower costs. Only in the long term (which is discounted by shareholders), when new capacity is deferred, do cost reductions exceed revenue reductions.

However, if the utility can sell DSM services to its customers, then its shareholders can make money on DSM in a competitive environment. The amount of earnings depends on the utility's cost of DSM and the price at which it can sell those services (Fig. 7). Shareholder earnings grow as costs go down and prices go up. Note that the utility has to sell DSM at a price higher than its cost to break even. This increment represents what would otherwise be the net lost revenues, almost $2 \mathrm{c} / \mathrm{kWh}$ in this example. 


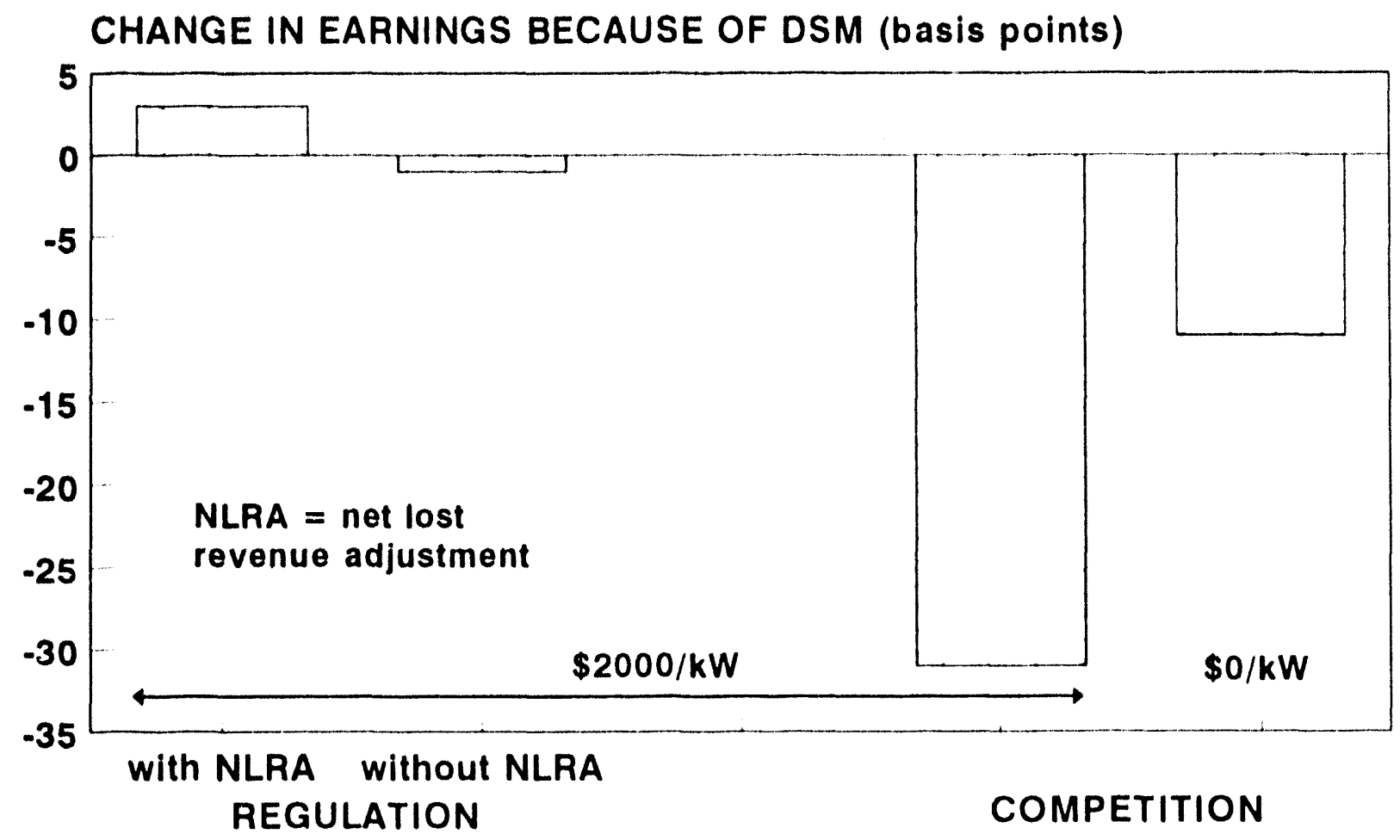

Fig. 6. Effects of a DSM program on shareholder earnings, assuming traditional regulation or full price competition.

CHANGE IN EARNINGS (basis points)

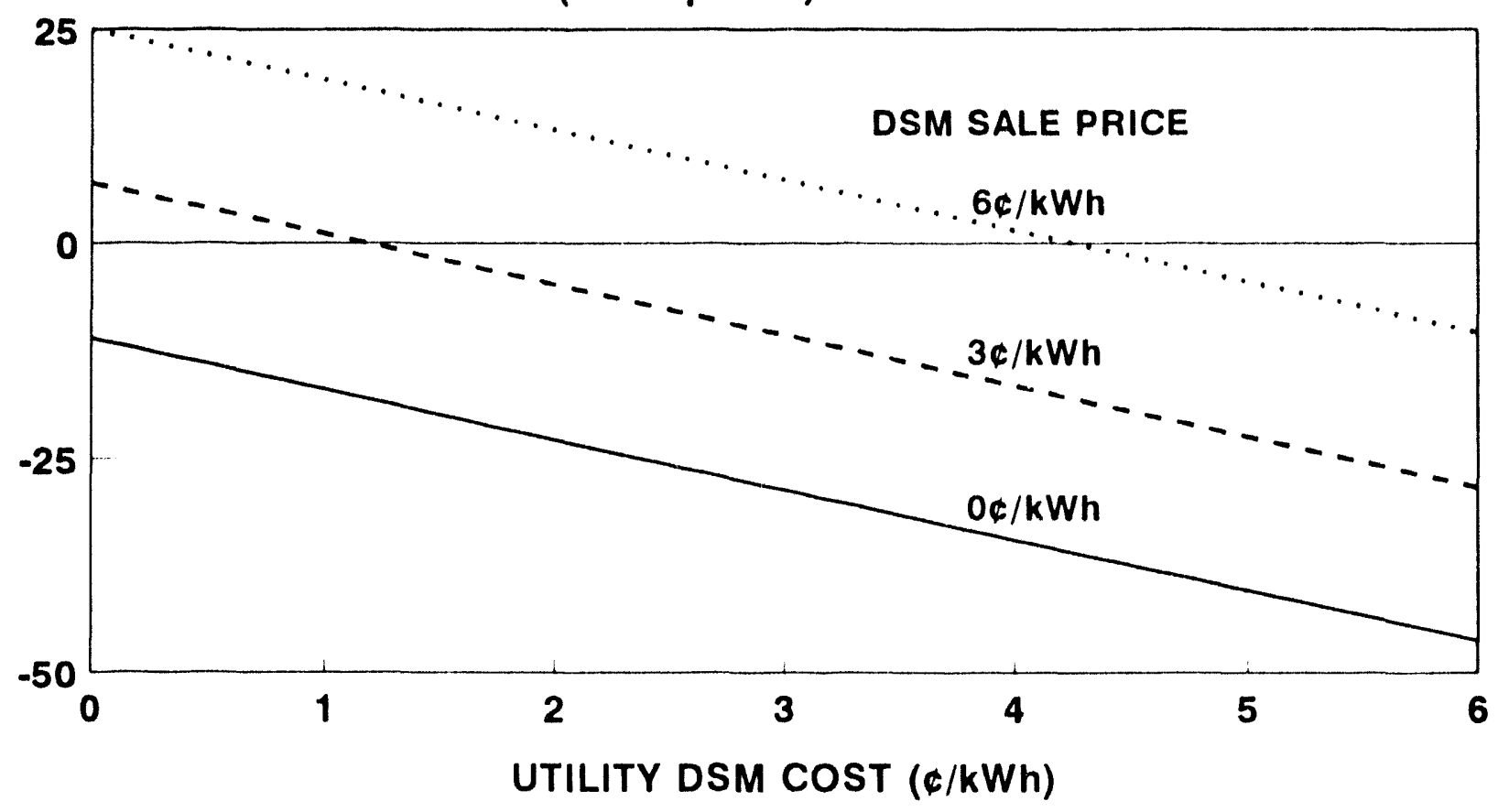

Fig. 7. Shareholder earnings in a competitive environment as functions of DSM costs and prices. 
In the traditional regulatory model, it is clear what lost revenues are and how they could be treated. It is not so clear in a competitive enviromment. On the one hand, if the utility helps customers become more energy efficient, customer electric bills will decrease, and the utility shareholders will lose earnings. However, if in a competitive environment, the customer would have made those efficiency improvements in any case (i.e., without assistance from the local utility), then the net lost revenue should not be charged against the DSM program. If the customer, absent the utility's DSM program, would have left the system, then the amount of revenue lost would have been much greater. Thus, defining a suitable reference against which to assess the benefits and costs of DSM programs may be more difficult in a competitive environment.

These examples emphasize the points made earlier. Utilities will need to understand much better the needs of various segments of their customers. If they fail to offer services that appeal to their customers, shareholders will likely lose money on DSM programs. And state regulators will need to ensure that utility shareholders are not penalized for running cost-effective DSM programs that benefit core customers and society in general. 


\section{CONCLUSIONS}

A critical issue, not addressed in this report, concerns how today's retail monopoly franchise, cost-of-service regulation will be transformed to a more competitive environment. Utilities are concerned that PUCs may not provide them with enough flexibility to respond appropriately to competitive threats. Others are worried that residential and small commercial customers will subsidize the larger customers that have market power and choices. And environmentalists worry that DSM programs may be a victim of the rush to competition.

Another key issue concerns environmental quality. Environmental concerns may play an important role in determining both the extent of retail wheeling and the nature of utility DSM programs. If, as seems likely, society places stricter controls on emissions of air and water pollutants and remains concerned about possible electromagnetic-field effects of transmission and distribution lines, then state regulators will likely require continuation or expansion of utility DSM programs. The Climate Challenge (part of the Climate Change Action Plan), includes a prominent role for U.S. electric utilities to reduce $\mathrm{CO}_{2}$ emissions. If the industry is largely fragmented, meeting the $\mathrm{CO}_{2}$-emission-reduction goals will be very difficult. Utilities can also play an important role in helping their customers meet cnvironmental regulations, as Southern California Edison and others are already doing.

As of early 1994, it is hard to know the extent to which competition will affect utility DSM programs. Nevertheless, it seems clear that competition at the retail level would have much more effect on DSM programs than would competition at the wholesale level. The extent to which retail competition occurs will depend strongly on the role that PUCs play. If PUCs allow or encourage retail wheeling, utility DSM programs that are financed by customers as a whole would be severely restricted. Utilities in that kind of an environment could generally run only those programs that paid for themselves. In other words, individual customers would have to pay for the DSM services that the utility provides. And that payment might have to include both the program costs and the utility's lost revenues.

If, on the other hand, PUCs limit retail wheeling or impose a fee on the use of the local utility's distribution system, DSM programs could continue much as they operate today. The number of customers covered by such programs would diminish because noncore customers would presumably not be eligible (or want) to participate in the utility's DSM programs. But utilities could continue to rely primarily on the TRC test rather than the RIM test in choosing DSM programs. Even here, however, utilities are likely to face strong pressure to keep rates low. This pressure, in turn, will require utilities to look for least-cost ways to implement DSM programs. In other words, the rate impact measure will be important here, although less so than in a full-blown retail-wheeling scenario. 
I see the following for utility DSM programs:

- They will focus more on customer service and less on the system-resource benelits.

- The resource benefits will emphasize capacity reductuons more and energy savings less. This shift will occur as utilities seek to minimize the lost revenues associated with DSM.

- From a resource perspective, DSM will become more cost-effective as utilities identify better ways to deliver DSM services at lower cost.

- Inter- and intraclass transfers will be reduced as utilities increasingly seck to have individual customers pay for their own DSM services.

Regardless of the extent of retail competition, the role of utility DSM will depend in large part on the ability of utilities to deliver DSM, to become more customer driven, and to lower the costs of DSM. Utilities will package DSM with other customer services, including pricing alternatives, reliability levels, power quality, and productivity improvements. All these DSM-program changes will require large changes in utility structure, operation, and culture. The challenge to regulators will be to retain the public benefits of traditional DSM programs in a more competitive environment.

\section{ACKNOWLEDGEMENTS}

I thank Douglas Bauer, Eric Blank, David Berry, Ralph Cavanagh, John Chamberlin, Shel Feldman, Jane Finleon, James Gallagher, John Hartnell, Patricia Herman, Lynn Hobbie, David Meyer, Diane Pirkey, Ralph Prahl, Dan Quigley, John Rowe, Richard Scheer, Martin Schweitzer, Bruce Tonn, and Michael Yokell for their very helpful comments on a draft of this report. I thank Fred O'Hara for editing and proofreading this report and I thank Ethel Schorn for helping in the preparation, printing, and distribution of the final report. 


\section{REFERENCES}

E. Blank 1993, "Minimizing Non-Participant DSM Rate Impacts-Without Harming Participation," The Electricity Journal 6(4), 32-41.

E. A. Bretz 1994, "Power Marketing: Wave of the Future?" Electrical World 208(2), 16, February.

California Public Utilities Commission and California Energy Commission 1987, Standard Practice Manual, Economic Analysis of Demand-Side Manageme'm Programs, San Francisco and Sacramento, CA, December.

California Public Utilities Commission 1993, California's Electric Servicess Industry: Perspectives on the Past, Strategies for the Future, Division of Strategic Planning, San Francisco, CA, February.

R. Cavanagh 1994, The Great "Re'uil Whecling" Illusion-And More Productive Energy Futures, Natural Resources Defense Council, New York, February.

J. Chamberlin, P. Herman, and G. Wikler 1993, "Mitigating Rate Impacts of DSM Programs," The Electricity Journal 6(9), 46-56, November.

W. J. Clinton and A. Gore, Jr. 1993, The Climare Change Action Plan, The White House, Washington, DC, October.

P. Corcoran 1994a, "The Conowingo Power Stranded Investment Case," Edison Times, Edison Electric Institute, Washington, DC, January.

P. Corcoran 1994b, "FERC Sets Transit Agency Case for Hearing," Edison Times, Edison Electric Institute, Washington, DC, February.

Demand-Side Report 1994, "Noresco Program for University of Rochester Heads Off Plans for Cogeneration Unit," 5, January 6.

Drazen-Brubaker \& Associates, Inc. 1993, "Survey of Power Costs in the Southeastern United States," prepared for the Tennessee Valley Industrial Committee, October.

Electric Power Research Institute 1994, Procecedings: 1994 Innovative Electricity Pricing, EPRI TR-103629, Palo Alto, CA, February. 
A. Faruqui and J. H. Chamberlin 1993, "The Trade-Off Between All-Ratepayer Benefits and Rate Impacts: An Exploratory Study," Proce'edings: Gih National Demand-Side Management Conference, Making a Diffier('nce, 31-37, EPRI TR-102021, Electric Power Research Institute, Palo Alto, CA, March.

T. Flanigan and A. Fleming 1993, "B.C. Hydro Flips a Market," Public Utilitie's Fortnightly 13/(15), 20-22, 34, Augusi 1.

J. Flood, L. Carmichael, and P. Vold 1994, "Automated Building Control and Real-Time Pricing: From Inception to Results," 117-123, Proce'edings: 1994 Innovative Electricity Pricing, EPRI TR-103629, Electric Power Research Institute, Palo Alto, C.A, February.

J. T. Gallagher 1994, personal communication, New York Department of Public Service, Albany, NY, March.

A. Hassan 1994, personal communication, Envest, Southern California Edison, Irwindale, C.A, March.

E. Hirst 1992, "Quantifying Tradeoffs Between Costs and Prices in Utility DSM Programs," The Electricity Journal 5(4), 16-24, May.

E. Hirst and E. Blank 1993, "Quantifying Regulatory Disincentives to Utility DSM Programs," Energy 18(11), 1091-1105, November.

E. Hirst and S. Hadley 1994, Effects of Resource Acquisitions on Utility Shareholders, draft, ORNL/CON-387, Oak Ridge National Laboratory, Oak Ridge, TN, March.

W. W. Hogan 1993, A Competitive Electricity Market Model, draft, Harvard Electricity Policy Group, Harvard University, Cambridge, MA, October.

L. J. Hopkins, R. E. Paquette, and F. P. Sioshansi 1994, "The Behavioral and Attitudinal Impact of End-Use Cost Information on Residential Customers," 55-64, Proceedings: 1994 Innovative Electricity Pricing, EPRI TR-103629, Electric Power Research Institute, Palo Alto, CA, February.

B. Howe 1993, "Distribution Transformers: A Growing Energy Savings Opportunity," Tech Update, TU-93-10, E Source, Boulder, CO, December.

J. P. Hughes 1993, In Defense of Retail Wheeling, Electricity Consumers Resource Council, Washington, DC, October.

D. Hunting ford and M. Nelson 1993, "Separate but Equal," Fortnightly 13/(21), 46-48, November 15 . 
M. J. Kelleher and L. L. Wood 1994, "Differentiated Services for Electric Utilities, Offering Options for Participating in Utility Programs," 229-236, Procecedings: 1994 Innovative Electricity Pricing, EPRI TR-103629, Electric Power Research Institute, Palo Alto, CA, February.

M. Keneipp, S. Bowden, R. Calhoun, R. Laurita, and D. Cohan 1993, Lessons Learned in Commercial Sector Demand-Side Management, EPRI TR-102551, prepared by RCG/Hagler, Bailly, Inc., and Xenergy, Inc., for Electric Power Research Institute, Palo Alto, C.A, October.

M. D. Levine, E. Hirst, J. G. Koomey, J. E. McMahon, and A. H. Sanstad 1994, Energy Efficiency, Market Fuilures, and Governme'nt Policy, Oak Ridge National Laboratory, Oak Ridge, TN, and Lawrence Berkeley Laboratory, Berkeley, CA, March.

D. Moskovitz, T. Austin, C. Harrington, and C. Weinberg 1993, Future Urility and Regulatory Structures: If You Don't Know Where You're Going. Any Road Will Ge' You There, Regulatory Assistance Project, Gardiner, ME, December.

Public Service Company of Colorado 1993, Integrated Resource Plan, A Balanced Approach to Mecting Customers' Future Electricity Ne'ds, Denver, CO, October.

M. Pye and S. Nadel 1994, Rure Impacts of DSM Programs: Looking Past the Rhetoric, draft, American Council for an Energy-Efficient Economy, Washington, DC, March.

R. B. Reich 1991, The Work of Narions, Preparing Ourselves for 21.5t-Century Capitalism, Alfred A. Knopf.

C. E. Richer 1993, "Demand-Side Management Revisited," Standard \& Poor's Creditweek, May 3.

H. Ruderman, M. D. Levine, and J. E. McMahon 1987, "The Behavior of the Market for Energy Efficiency in Residential Appliances Including Heating and Cooling Equipment," The Energy Journal 8(1), 101-124.

R. J. Rudden Associates and Fitch Investors Service 1993, Electric Utility Competition: $A$ Survey of Regulators, Hauppauge, NY, November.

Southern California Edison 1993, Questions and Answers, Self-Generation Deferral Rate, Rosemead, CA, March.

C. Stone 1993, “DSM Skills Are Marketing Skills," Fortmightly 13/(18), 26-30, October 1.

R. J. Sutherland 1991, "Market Barriers to Energy-Efficiency Investments," The Energy Journal 12(3), 15-34. 
B. Tonn and A. Schafthauser 1994, Perspectives on the Future of the Electric Utility Industry, ORNL/CON-385, Oak Ridge National Laboratory, Oak Ridge, TN, March.

U.S. Congress 1978, Public Utility Regulatory Policies Act, P.L. 95-617, Washington, DC, December.

U.S. Congress 1992, Energy Policy Act of 1992, P.L. 102-486, Washington, DC, October 24. 


\section{INTERNAL DISTRIBUTION}

1. D. Bauer

2. L. Baxter

3. V. D. Baxter

4. L. Berry

5. D. S. Bjornstad

6. R. Braid

7. M. A. Brown

8. J. B. Cannon

9. R. S. Carlsmith

10. F. C. Chen

11. J. Christian

12. G. Courville

13. T. R. Curlee

14. P. D. Fairchild

15. W. Fulkerson

16. L. J. Hill

17. E. Hillsman

18. E. Hirst

19. P. J. Hughes

20. J. O. Kolb

21. M. A. Kuliasha
22. R. Lee

23. P. Leiby

24. J. M. MacDonald

25. V. C. Mei

26. W. R. Mixon

27. S. Purucker

28. D. E. Reichle

29. D. T. Rizy

30. M. Schweitzer

31. R. B. Shelton

32. B. E. Tonn

33. J. Van Dyke

34. J. Vancoevering

35. J. M. Veigel (ORAU)

36. D. L. White

37. T. J. Wilbanks

38. ORNL patent Office

39. Central Research Office

40. Document Reference Section

41. Laboratory Records (RC)

42-44. Laboratory Records Dept.

\section{EXTERNAL DISTRIBUTION}

45. Dr. Douglas R. Bohi, Director, Energy and Natural Resources Division, Resources for the Future, 1616 P Street, N.W., Washington, DC 20036

46. Dr. Thomas E. Drabek, Professor, Department of Sociology, University of Denver, Denver, Colorado 80208-0209

47. Calvin MacCracken, President, Calmac Manufacturing Corporation, 101 West Sheffield Avenue, P. O. Box 710, Englewood, NJ 07631

48. Jacqueline B. Shrago, Director, Office of Technology Transfer, 405 Kirkland Hall, Vanderbilt University, Nashville, TN 37240

49. Mr. George F. Sowers, P. E., Senior Vice President, Law Companies Group, Inc., 114 Townpark Drive, Suite 250, Kennesaw, Georgia 30144-5599

50. Dr. C. Michael Walton, Ernest H. Cockrell Centennial Chair in Engineering and Chairman, Department of Civil Engineering, University of Texas at Austin, Austin, Texas 78712-1076

51.-52. OSTI, U. S. Department of Energy, P. O. Box 62, Oak Ridge, Tennessee 37831 53. Office of Assistant Manager for Energy Research and Development, DOE/ORO, P. O. Box 2001 Oak Ridge, TN 37831-8600

54.-750. External Energy Efficiency and Renewables Section Distribution Mailing List and extra copies to E.M. Schorn, 4500N, H-19A 
11

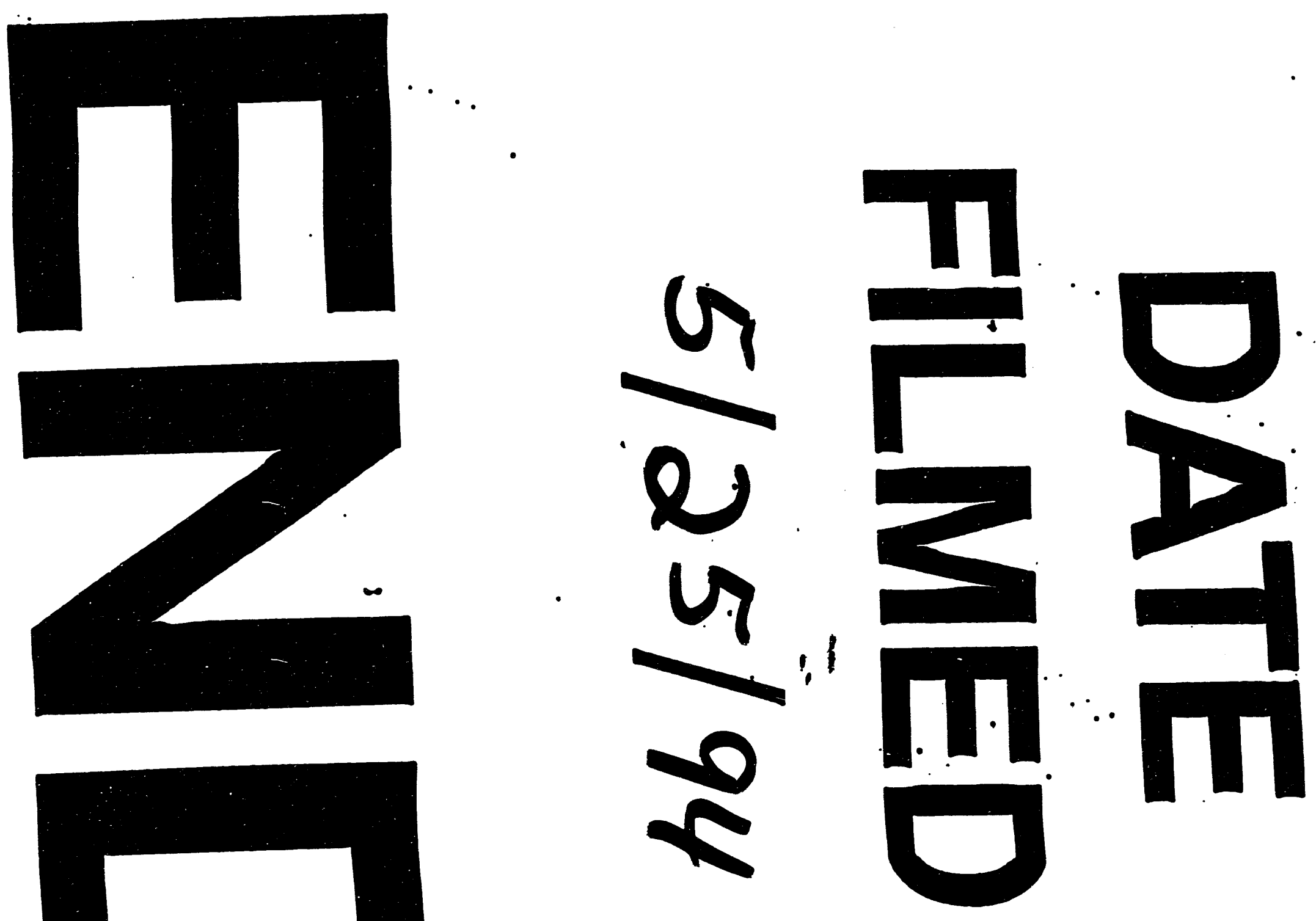


